\title{
On the Relationship between Schwartz's Value Orientation and Willingness to Communicate: The Case of Iranian University Students
}

\author{
Mohammad Ali Izadpanah ${ }^{1, *}$, Fatemeh Rakhshandehroo ${ }^{2}$, Mehrnoosh Eslami², \\ Mahmoud shaker ${ }^{2}$ \\ ${ }^{1}$ Shiraz University, Shiraz, Iran \\ ${ }^{2}$ University of Applied Science and Technology, Shiraz Khabar Media School, Shiraz , Iran
}

\begin{abstract}
Values have always been one of the fundamental concepts in social studies. This is while the reconstruction of our values deeply influences language proficiency and willingness to communicate in a second language. Therefore, the present study attempts to investigate any probable interaction between individuals' value orientations and their willingness to communicate. To this end and in order to determine the values of the participants, a Persian-translated Portrait Values Questionnaire (PVQ) was distributed among 500 Iranian university students (296 females and 204 males). Additionally, the same group of participants filled out the Persian modified version of MacIntyre, Baker, Clement, and Conrod's Willingness to communicate questionnaire (MacIntyre et al, 2001) which was employed to put a figure on the participants' willingness to communicate in the context of the classroom. The conclusions derived from this study revealed that the existence of a positive relationship between overall WTC and value orientation as well as WTC subcomponents and that of value orientation. Furthermore, the results obtained through stepwise regression analysis indicated that in terms of values, openness to change, self-enhancement, universalism, tradition, and self-direction are better indicators of overall WTC. The findings also indicated that although gender affected participants' willingness to read and speak in the classroom, it did not have any significant effect on their value orientations. The results of the study can improve the researchers' comprehension of the nature of the connection among basic human values and willingness to communicate among Iranian university students.
\end{abstract}

Received 6 October 2017 Accepted 12 February 2018

Keywords: Willingness to Communicate, Reading Comprehension, Reading Components, Portrait Value Questionnaire 


\section{Introduction}

Most experts in different fields of language studies unanimously agree upon the simplistic and allencompassing definition of language which states that "Language is a means of communication" (Dummet, 1981). Based on this definition, Dummet (1981) is implying that language is primarily purported to grease the wheels of communication. In doing so, this magical device enables us to encode our intention, knowledge, emotion, belief, propaganda, and other various forms of meaning in a complicated and intricate verbal or written system to get them across and, at the other side of the continuum, decode them back into thoughts (Dummet, 1981). Based on this simple, but crucial, continuum, recent language teaching and learning literature has put emphasis on promoting communicative competence among second language (L2) learners (Canale \& Swain, 1980, as cited by Peng, 2007). Despite all the efforts to cultivate communicative capabilities among second language learners, it was reported by Dornyei (2003) that many proficient L2 learners are likely to escape from L2 communication. The tendency or in other words "willingness" to interact, on the other hand, is found to be one of the determining factors affecting an individual's first language acquisition and mastery over the second language (Skehan, 1989). Kang (2005) concludes it in essence: "it can be assumed that more interaction leads to more language development and learning" (Kang, 2005).

Burgoon (1976) was the first researcher who constructed "Unwillingness to Communicate" as an "enduring and chronic tendency to avoid or devalue oral communication" (Burgoon, 1976). She added that anomie, self-esteem, and introversion are factors which can have an impact on an individual's willingness to communicate in various communicative situations (Burgoon, 1976). McCroskey and Richmond (1987) proposed willingness to communication as the "individuals' tendency to willingly initiate communication with reference to the use of the first tongue" (McCroskey and Richmond, 1987, as cited by Zarrinabadi and Abdi, 2011). Trying to reconstruct the notion of willingness to communication (WTC) in a second language context, it was later hypothesized by MacIntyre, Clement, Dorneyi, and Noels (1998) that WTC is a situational variable in order to put the emphasis on the idiosyncratic and contextual impacts in the initiation of L2 communication.

They defined WTC as "a readiness to enter into discourse at a particular time with a specific person using an L2" (MacIntyre, Dörnyei, Clément, \& Noels, 1998, p. 547, as cited by Zarrinabadi and Abdi, 2011). MacIntyre et al.'s six-level pyramid model (1998) introduces some variables (layers) affecting an individual's WTC (MacIntyre et al, 1998).

In the first three layers of MacIntyre et al's model, situational factors with the context-specific influencing an individual's WTC are discussed, while the next three layers center around the context-free and long-term influences on WTC (Zarrinabadi \& Abdi, 2011). The opening layer of the model consists of the ability to authentically communicate in the second language which encompasses the ability to read or speak in a second language in the context of the schoolroom. The third layer focuses on the willingness to communicate with specific individuals as a prerequisite which requires confidence, namely, having the ability of communicating effectively in specific situations. The fourth layer discusses the role of motivational inclinations: interpersonal 
motivation, intergroup motivation, and motivation towards the interlocutor. The fifth layer is allocated to the factors which are beyond language learning and communicative events and more related to affective-cognitive context: intergroup attitude, social situation and communicative competence. The final layer encompassing social and individual context is considered to be the most isolated one with minimum impact on communication.

It is argued by Demir et al (2012) that values are considered as significant concepts that can make socio-cultural elements of the society meaningful. Fichter considers a value to be any element that is useful for, demandable for, or liked by an individual or a group of individuals (Fichter, 1990). According to Beill, the ability to distinguish between what he regards "the good and the bad" (Beill's terms, 2003) and between "the right and the wrong" (Beill's terms, 2003) via social rules, customs and traditions, hence leading to the learning of a baseline that corresponds with their own moral values (Beill, 2003). Despite the fact that studies in the field of social sciences have provided different definitions for values and have adhered to different approaches to define this concept (which will be covered in the subsequent sections of the present study). By interacting with the environment in the process of socialization, the individuals internalize values which are defined as a permanent consideration and standard (Başbakanlık, 2010; Özsoy, 2007).

A systematic theory of the content and organization of the value systems of individuals has only been proposed and empirically validated by Schwartz in the past decade (Schwartz, 1992). Schwartz's theory identifies ten different types of values which are known amongst different cultures and specifies the clashes and congruities that exist between them (Schwartz et al, 2001).

It is argued by Schwartz that personal values (such as security and power) are constructs which are motivational and related to trans-situational goals with different levels of significance which act as the guiding light of an individual's life or other, as put by Schwartz, "social entity" (Schwartz, 1994).

In this sense the values of children are believed to have a central effect in educational settings (Doring, 2010). It is added by Doring that parents, teachers, educators, trainers, and other practitioners, all over the world, are worried about encouraging ethical growth as well as constructing childrens' ethical character (Doring, 2010). It is then stated that a large number of resources explicitly aiming at the transmission of values have been developed, meaning that transmission of value is highly recognized and brought into attention by the public interest.

\section{Schwartz's Value Theory}

According to their underlying goals, 10 basic values were defined by Schwartz (1992) (see Table 1). The mere existence of such values and the relations existent among them are supported by data obtained from more than 80 sampled countries (Fig. 1). The main element that signifies Schwartz's theory $(1992,1994)$ among others are the theoretical relationships that exist between the values presented in his model, significantly adding to our comprehension of how different behaviors are motivated by values. 
Table 1. Schwartz's 10 value orientations and the associated individual level values items

\begin{tabular}{|c|c|}
\hline Value-Type Definitions & Value Items For Each Value Type \\
\hline $\begin{array}{l}\text { Power: Social status and prestige, control or dominance } \\
\text { over people and resources. }\end{array}$ & Social power, authority, wealth \\
\hline $\begin{array}{l}\text { Achievement: Personal success through demonstrating } \\
\text { competence according to social standards. }\end{array}$ & Successful, capable, ambitious, influential \\
\hline $\begin{array}{l}\text { Hedonism: Pleasure and sensuous gratification for } \\
\text { oneself }\end{array}$ & Pleasure, enjoying life, self-indulgent \\
\hline Stimulation: Excitement, novelty, and challenge in life & Daring, a varied life, an exciting life \\
\hline $\begin{array}{l}\text { Self-direction: Independent thought and action- } \\
\text { choosing, creating, exploring }\end{array}$ & $\begin{array}{l}\text { Creativity, curious, freedom, independent, choosing } \\
\text { own goals }\end{array}$ \\
\hline $\begin{array}{l}\text { Universalism: Understanding, appreciation, tolerance, } \\
\text { and protection for the welfare of all people and for } \\
\text { nature }\end{array}$ & $\begin{array}{l}\text { Equality, a world at peace, social justice, broadminded, } \\
\text { wisdom } \\
\text { Protecting the environment, a world of beauty, unity } \\
\text { with nature }\end{array}$ \\
\hline $\begin{array}{l}\text { Benevolence: Preservation and enhancement of the } \\
\text { welfare of people with whom one is in frequent personal } \\
\text { contact }\end{array}$ & Helpful, honest, forgiving, loyal, responsible \\
\hline $\begin{array}{l}\text { Tradition: Respect, commitment, and acceptance of the } \\
\text { customs and ideas that traditional culture or religion } \\
\text { provide }\end{array}$ & $\begin{array}{l}\text { Humble, devout, accepting my portion in life, respect } \\
\text { for tradition, moderate }\end{array}$ \\
\hline $\begin{array}{l}\text { Conformity: Restraint of actions, inclinations, and } \\
\text { impulses likely to upset or harm others and violate social } \\
\text { expectations or norms }\end{array}$ & $\begin{array}{l}\text { Politeness, obedient, honouring parents and elders, } \\
\text { self-discipline }\end{array}$ \\
\hline $\begin{array}{l}\text { Security: Safety, harmony, and stability of society, of } \\
\text { relationships, and of self }\end{array}$ & $\begin{array}{l}\text { National security, social order, clean, family security, } \\
\text { reciprocation of favours }\end{array}$ \\
\hline
\end{tabular}

Note. Adapted from Lee et al. (2008)

\section{Conservation}

Security, Tradition,

Conformity

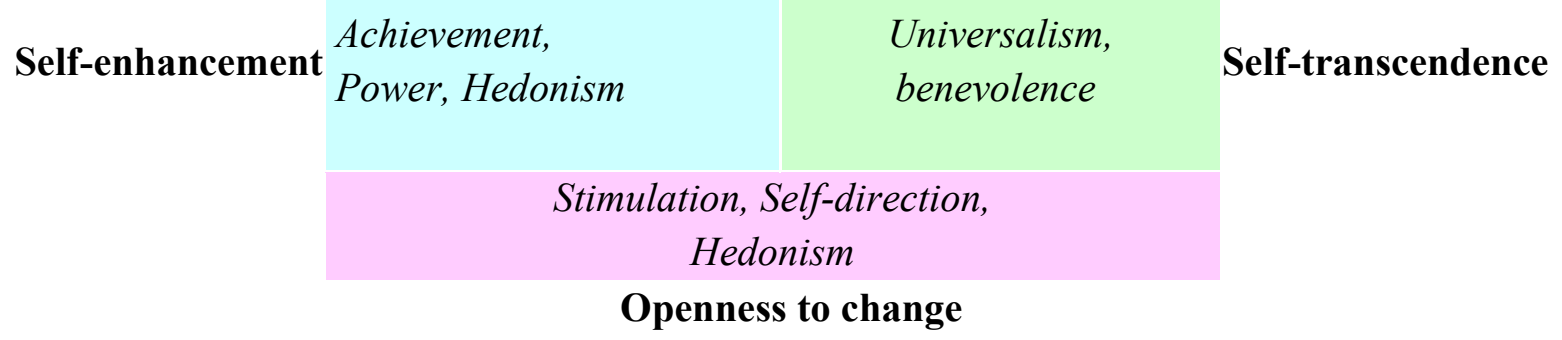

In earlier versions of Schwartz's value theory (Schwartz, 1992), the possibility was raised that another near-universal value, namely spirituality, might be added to the model but more recently it was stated by Schwartz that the defining goal of spiritual values lies in meaning, coherence, and inner harmony through transcending everyday reality (Schwartz, 2010). Finding ultimate meaning as a basic human need can lead us to consider spirituality as a distinct value that can be found everywhere (e.g., Niebuhr, 1935, as cited in Schwartz, 2010). As a result, the value survey 
presented by Schwartz contained specific spirituality markers, gathered from widely different sources (Schwartz, 2010).

\section{The Structure of Value Relations}

Schwartz not only identifies these ten basic values but also explains the arrangement of dynamic relationships that exist between them (Scwartz, 2010). Based on this theory the value structure arises from the fact that any type of action taken in order to fulfill one value will lead to conflict with a number of values values while being in accordance with others (Schwartz, 2010). Schwartz's example is illustrated in terms of the conflict which arises when attempting to pursue achievement values with pursuing values of benevolence values while at the same time chasing both values of achievement and power at the same time is usually compatible (Schwartz, 2010). Schwartz also argues that actions aimed at enhancing one's own social position and authority over others strengthen eagerness to seek personal success for oneself (Schwartz, 2010). He also adds that if one is after novelty and change (which constitute stimulation values) they are not going to pursue and keep customs honored by time (i.e., tradition values) (Schwartz, 2010). On the contrary, it is mentioned by Schwartz that pursuing traditional values and conformity values are in congruity with each other both motivating actions of submission to external expectations (Schwartz, 2010).

Schwartz argues that if actions are regarded as a quest to find values the consequences will have practical, psychological, and social impacts (Schwartz, 2010). Hence, it can be concluded that the meaning of this is that the selection of an alternative action promoting one value is likely to breach or disrupt the opposite value leading the person who is trying to choose their next action to feel that such alternative actions are psychologically inharmonious while, on the other hand, social sanctions may be imposed by others by aiming at practical and logical discrepancies between an action and other values the person holds (Schwartz, 2010).

Schwartz's circular structure portrayed by Figure 1 indicates the overall arrangement of relationships of encounter and harmony amongst values (Schwartz, 2010). Based on this model the two values of tradition and conformity are positioned in the same wedge given that they share similar extensive motivational goals (Schwartz, 2010). The center of the model mainly encompasses conformity while tradition has moved towards the margins signifying the fact that there is stronger opposing forces among values of tradition values and other opposing values (Schwartz, 2010). Based on Schwartz value model, depicted in Figure 1, abstractness and absoluteness are more likely to be found among expectations which are linked to tradition in comparison with conformity values that are based on interactions, hence demanding a tougher, unambiguous dismissal of values that oppose each other (Schwartz, 2010).

In order to summarize the oppositions that exist between competing values we must consider them to be organized along two bipolar dimensions (Schwartz, 2010). Based on Figure 1 from Schwartz's model (2010), in one dimension openness to change and conservation values are contrasted against each other, in this manner capturing clash among values emphasizing through independence, act, emotions, and readiness to embrace change (self-direction, stimulation) and 
those such as security, conformity, tradition which are emphasizing order, self-restriction, past preservation, and resistance to change (terms coined by Schwartz, 2010). In the second dimension of the model self-enhancement and self-transcendence values which indicate and existing conflict among values emphasizing welfare concerns and others' interests (universalism, benevolence) alongside values such as power and achievement emphasizing how an individual must chase their own welfares and related success as well as their supremacy over others (Schwartz, 2010). Finally, elements of both openness to change and self-enhancement are shared by hedonism (Schwartz, 2010).

Although Schwartz's model distinguishes ten values of interest it does come to form the hypothesis that all values build a range of motivations related to each other at a more basic level, hence leading to the formation of the circular structure (Schwartz, 2010). The present study has noted the shared motivational emphases of adjacent values in order to clarify the nature of the continuum (Schwartz, 2010): To clarify the nature of the continuum, the shared motivational emphases of adjacent values are noted in the present study: (a) power and achievement--social superiority and esteem; (b) achievement and hedonism--self-centered satisfaction; (c) hedonism and stimulation--a desire for affectively pleasant arousal; (d) stimulation and self-direction-intrinsic interest in novelty and mastery; (e) self-direction and universalism--reliance upon one's own judgment and comfort with the diversity of existence; (f) universalism and benevolence-enhancement of others and transcendence of selfish interests; (g) benevolence and tradition-devotion to one's in-group; (h) benevolence and conformity--normative behavior that promotes close relationships; (i) conformity and tradition--subordination of self in favor of socially imposed expectations; (j) tradition and security--preserving existing social arrangements that give certainty to life; (k) conformity and security--protection of order and harmony in relations; (1) security and power--avoiding or overcoming threats by controlling relationships and resources.

Self-Transcendence values (Universalism and Benevolence)

Self-Enhancement values (Hedonism and Power).

Conservation values (Security and Conformity)

Openness to Change values (Independence and Stimulation)

Overall, it is argued by Schwartz (2010) that a motivational continuum is presented by the circular arrangement of the values. Closer proximity of values in both directions around a circle leads to more similar underlying motivations shared by them; an increase in the distance, thought, will lead to stronger opposing of motivations (Schwartz, 2010). There are critical implications regarding the idea that values form motivational continuum: the division presented by Schwartz for values can be considered as an arbitrary convenience, giving reason to the division "of the domain value items less fine-tuned distinct values according to the needs and objectives of an individual's analysis" (Schwartz, 2010).

\section{Values and Behavior}

The first attempts to comprehend behaviors in the organizational environment from the values of the people who work in it started in the 1960s (Tagiuri, 1965). The earliest studies in this regard 
centered on studying the effect of value orientations upon the relationship between managers and scientists (Tagiuri, 1965) as well as the investigation of how personal values affect corporate strategy (Guth \& Tagiuri, 1965). In the next decade studies focusing on using managers' values to explain how they behave was pointed out by studies conducted by England $(1967,1975)$ and England \& Lee (1974).

A study with a scale for measuring values based on Spranger's taxonomy (Spranger, 1928) was carried out by Guth \& Tagiuri (1965), while England's (1967, 1975) study was conducted based on a model seeking to clarify the behavior of a taxonomy classifying values into two types operative values and intended, adopted values - with the first having impacts on decision-making and problem-solving behaviors and the latter acting as a filter used to interpret data that come from the social environment in which the individuals insert themselves into (England, 1967,1975). by considering the influence of the environment along with its restrictions and stimuli helped England (1967) was able to complete the explicative model of behavior (England, 1967).

The 1960s was a time in which based on Spranger (1928) Allport et al (1960) developed an AVL scale of measurement for values.

Another scale of measurement of values arose in the 1960s, based on Spranger (1928), the AVL scale developed by Allport, Vernon and Lindzey (1960). These studies continued in future years with Rokeach's studies in the 70s (Rokeach, 1973). Rokeach not only introduced and developed an ordinal scale for values (RVS - Rokeach Value Survey), but also suggested a taxonomy which divided the values into terminal and instrumental, the latter regarding moral conduct and competency valorization (Oyadomari, 2008).

It is proposed by Schwartz (1992) that the basic values meet three universal needs of human beings: a) their needs as organic beings; b) their needs for coordinated social interaction; and c) the need for the functioning maintenance and survival of the groups (Schwartz, 1992). These ten values have a circular relationship amongst them, while they keep compatibilities and oppositions among each other and correspond to two bipolar dimensions: self-promotion versus selftranscendence and openness to change versus conservation (Schwartz, 1992). It is argued by Schwartz that by having the possibility to make a prediction regarding the relationship between the poles of each of the value dimensions and behavioral variables, a direct relationship between values and behavior is thus established (Schwartz, 1992) which is in contradiction with Rokeach's beliefs of values having impact on behaviors via attitudes (Rokeach, 1973).

Some researchers such as Rohan (2000), similar to England (1967) and Rokeach (1973), concede that there are other factors related to basic or personal values which can provide an explanation regarding the relationship between values and behavior. Based on Rohan's views regarding values, individuals perceive values inflicted upon them by society and which they then utilize to evaluate the behavior of other interlocutors, their own views of the world as well as their ideology (Rohan, 2000).

\section{Differences between Values of Males and Females}


In terms of the differences that lie between males and females in terms of the effects of gender equality in values priorities, Schwartz and Rubel (2005) conducted a study in which they recruited 127 samples from 70 countries proved consistent cross-cultural sex differences for seven out of the 10 basic human values. The results of their study indicated that women associated more with benevolence and universalism values comparing to their male counterparts. Men, on the other hand, associated more with power, hedonism, stimulation, achievement, and values. With a lesser amount of consistency, women attributed more prominence to security values. For tradition and conformity values, there found to be no significant sex difference (Schwartz \& Rubel, 2005).

\section{Values and Willingness to Communicate}

While a wide range of studies were found which had focused on willingness to communicate and the effect of gender and other variables on such type of willingness and another range of studies was found on values and how they can affect behavior, no specific instance was found in which these two concepts, namely values and willingness to communicate, had been investigated and the impacts of one on the other studied. Hence, the present study is an attempt to put these two important variables alongside each other and assess whether having specific values can predict a certain aspect of willingness to communicate in Iranian EFL learners.

\section{The present study}

From the assumption that human values can affect behaviors that reveal task-achievement orientation, identity, and motivation towards a particular action, in this study attempt is made to investigate the probable relationship between the amount of willingness Iranian English learners show towards learning the target language and how such willingness is affected by their value priorities. In other words, if individuals' values are able to change their behaviors, it seems plausible to think of the possible impact these alternations might have on their language learning behaviors. In short, the present study tries to examine any probable interaction between basic value priorities of individuals and which language skills (speaking, reading, writing, comprehension) they are most likely to excel at. Moreover, the present study can be assumed as the first attempt to investigate the current issue.

\section{Method}

\section{Participants}

The participants of this study were 500 (female $=272$, male $=228$ ) university B.A. and B.S. holders (female $=189$, male $=139$ ) who had been accepted in the M.A entrance exam and entered Shiraz university for the academic year of 2012-2013. They were either majoring in humanities, pure sciences, or medicine. These students, no matter what their academic major is, are required to take part in an English Exemption test before beginning their studies as M.A students at Shiraz University. The participants' age ranged from 25 to 35 and the questionnaires were completed before the exam was administered. These participants completed MacIntyre et al's WTC and 
Shwartz's PVQ questionnaires. In order to know how to complete the questionnaires instructions were provided by the researchers.

\section{Instruments}

In order to conduct this study two main instruments were used MacIntyre et al's WTC questionnaire and Shwartz's PVQ questionnaire, each of which were back-translated to Persian with the help of Shiraz University M.A TEFL faculty. The detailed specifications of each questionnaire are given below:

\section{MacIntyre et al's willingness to communicate questionnaire}

A Persian adaptation of the Likert-type questionnaire MacIntyre et al. (2001) developed was employed to measure the participants' willingness to communicate inside the classroom. The translated version had been handed to one psychology professor to check the consistency of meaning and was back translated with the aid of professors from the English Language Department at Shiraz University. The questionnaire included 27 items ranging from 1 to $5(1=$ almost never willing, $2=$ sometimes willing, $3=$ willing half of the time, $4=$ usually willing, and $5=$ almost always willing). Participants were asked to indicate how much they are willing to communicate in class tasks centering on all four language skills. According to MacIntyre et al. (2001), the questionnaire is valid and reliable based on the following measures: speaking ( 8 items, $\alpha=.79$ ), comprehension (5 items, $\alpha=.81$ ), reading ( 6 items, $\alpha=.80$ ), and writing ( 8 items, $\alpha=.82$ ). The alpha reliability estimates were: speaking ( 8 items, $\alpha=.81$ ), comprehension ( 5 items, $\alpha=.78$ ), reading ( 6 items, $\alpha=.82$ ), and writing ( 8 items, $\alpha=.82$ ).

\section{Schwartz Portrait value questionnaire}

Value orientations of the individuals were measured by the Persian translated version of the Portrait Values Questionnaire (Schwartz et al., 2001), which comprises of 40 brief two sentence statements. These short verbal portraits are descriptions of 40 different people, gender-matched with the respondent (Schwartz, et al., 2001). Participants rated their value priorities based on a Likert scale 1 (not at all like me) to 5 (very much like me). Each portrait pictures a person's goals, aspirations, or wishes to the extent to which it can be considered a value. Schwartz's Portrait Values Questionnaire included Power, Achievement, Hedonism, Stimulation, Self-direction, Universalism, Benevolence, Tradition, Conformity and Security values. For instance: "It is important to him to be rich. He wants to have a lot of money and expensive things" describes a person who cherishes power values (Schwartz, 1992). This questionnaire was translated into Persian language by the researchers themselves. The translated version had been handed to a sociology professor to check the consistency in meaning and readability and was back translated with the assistance of professors from the English Language Department at Shiraz University. Cronbach alphas were .70 for Power, .72 for Achievement, .80 for Hedonism, .63 for Stimulation, .65 for Self-Direction, .75 for Universalism, .64 for Benevolence, .61 for Tradition, .58 for Conformity, and .59 for Security. 


\section{Procedures}

This study was carried out based on two questionnaires. Firstly, a Persian translated of PVQ was employed to collect the data on the participants' value priorities. The questionnaire was handed to the participants by the researchers themselves. The researchers provided the participants with a brief clarification on the questionnaire itself and the research aiming to avoid any possible confusion. It took about 2 hours to orient participants to fill out the questionnaires and to collect the answer sheets. Having filled out the questionnaires, the obtained data was analyzed via SPSS 19 package. In order to see whether any relationship exists between WTC total and subcomponents with the participants PVQ correlational analysis was conducted and in order to see whether the participants' WTC total and its subcomponents can be predicted by their values Stepwise Regression was applied. The results of these analyses are presented in detail in the following.

\section{Results and discussion}

As stated earlier in order to obtain information on whether there is a relationship between WTC total and its subcomponents with their PVQ, correlational analysis was run and in order to indicate whether overall WTC can be predicted by elements of PVQ stepwise regression was run on the data.

\section{Correlational Analysis}

A correlational analysis was run on the data to explore the relationship between the total of WTC with the subcomponents of Portrait Values Questionnaire developed by Schwartz et al.(2001), the correlation between the subcomponents of WTC with PVQ components was also explored. In order to determine which subcomponent of PVQ had the strongest correlation with components of the participants' WTC, each PVQ subcomponent was separately investigated in terms of its relationship with the participants' willingness to speak, read, write, and comprehend the target language, namely, English. The results of this analysis appear in Table 2 below.

Correlations between the PVQ components and overall WTC and its subcomponents are presented in Table 2. Based on the results obtained there was a positive relationship between WTC total and all subcomponents of PVQ except, Tradition, Security, Conformity, and Conservation.

Table 2. Correlation between WTC and PVQ subcomponents

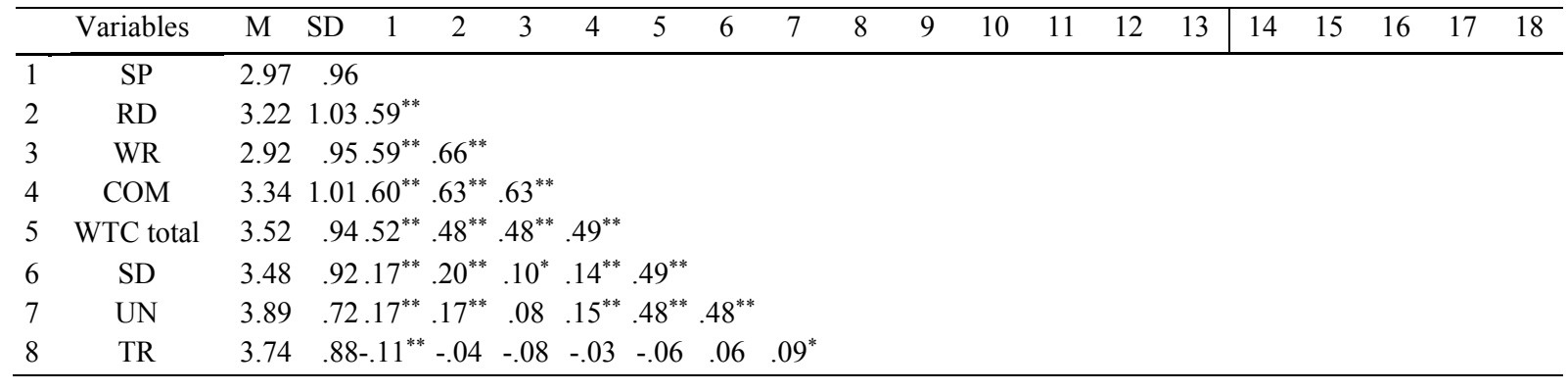




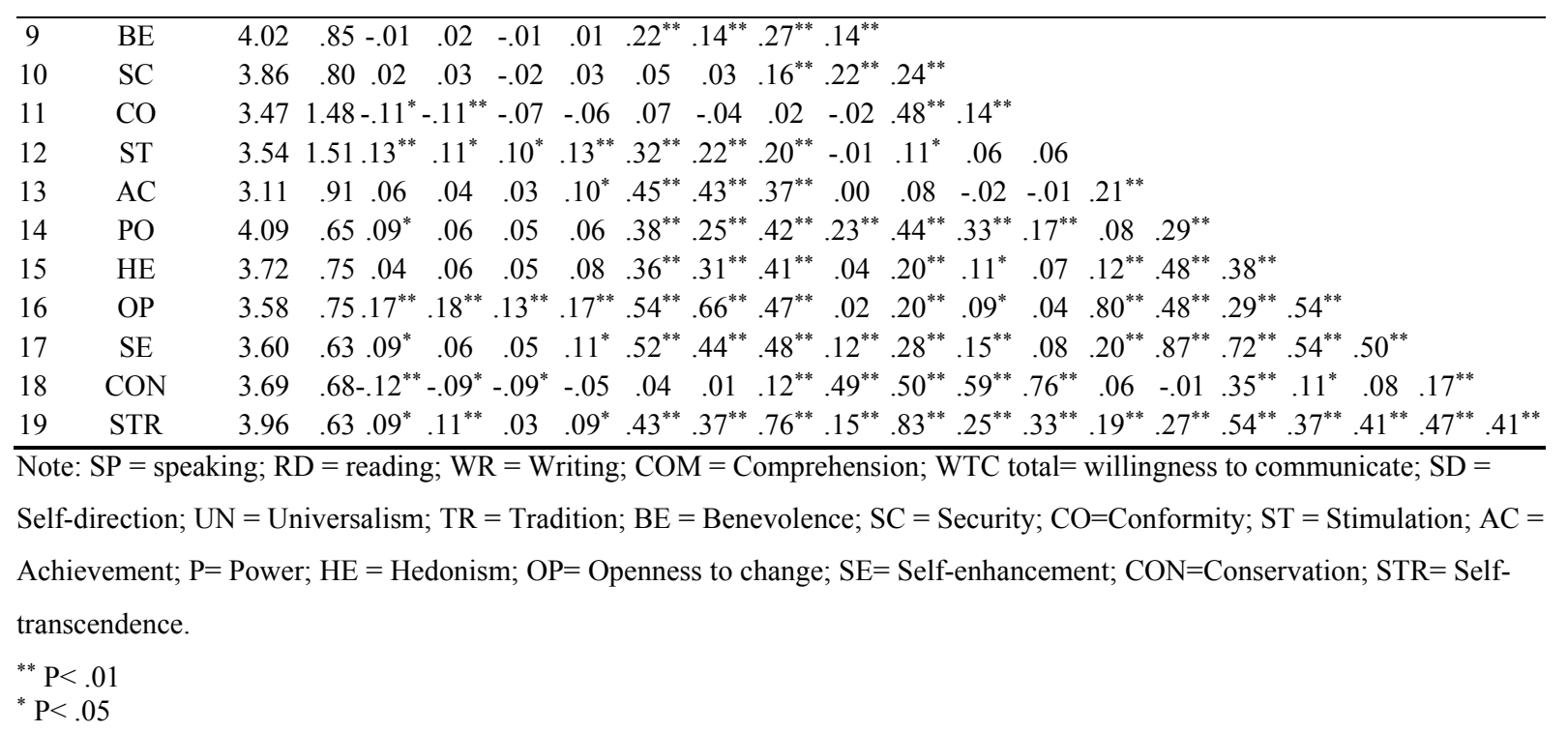

Based on the results in Table 2, it was found that individuals who had a higher overall WTC total were ones which had the highest correlation with participants' whose values mainly centered on self-direction, universalism, benevolence, stimulation, achievement, power, hedonism, openness to change, self-openness, and self-transcendence $(\mathrm{p}<.01)$. The results additionally indicatedzho

I (Table 2), the significant correlation between the subcomponents of WTC and the subcomponents of PVQ by which they were affected included speaking which was affected by self-direction, universalism, tradition, stimulation, openness to change, conservation, and selftranscendence $(\mathrm{p}<.01)$ as well as power, self-enhancement, and conformity $(\mathrm{p}<.05)$; reading which was affected by self-direction, universalism, conformity, openness to change, and selftranscendence $(\mathrm{p}<.01)$ as well as power, self-enhancement, and stimulation and conservation $(p<.05)$; the least correlation was found between writing skill and PVQ elements of openness to change $(p<.01)$ as well as self-direction, stimulation, and conservation $(p<.05)$; the final WTC subcomponent of WTC, comprehension, positively correlated with self-direction, universalism, stimulation and openness to change $(p<.01)$, as well as with achievement, self-enhancement and self-transcendence $(p<.05)$. Hence, regarding overall WTC and its correlation with the values of the participants significant correlation was found between WTC total and PVQ values of selfdirection, universalism, benevolence, stimulation, achievement, power, hedonism and selftranscendence $(\mathrm{p}<.01)$.

\section{Stepwise Regression}

A stepwise regression was run on the obtained data to indicate which values were the best predicators of the participants' WTC total.

Table 3: Step wise regression analysis of WTC on value orientation components

\begin{tabular}{l|l|l|l|l|l|l|l|l}
\hline Model $^{*}$ & & $\mathrm{R}$ & $\mathrm{R}^{2}$ & $\mathrm{~F}$ & Sig. & $\beta$ & $\mathrm{T}$ & Sig. \\
\hline
\end{tabular}




\begin{tabular}{l|l|c|c|c|c|c|c|c}
\hline 1 & Openness to change & .545 & .297 & 210.67 & .0001 & .227 & 4.69 & .0001 \\
\hline 2 & Self-enhancement & .616 & .379 & 151.56 & .0001 & .265 & 6.36 & .0001 \\
\hline 3 & Universalism & .640 & .410 & 114.86 & .0001 & .195 & 4.69 & .0001 \\
\hline 4 & Tradition & .654 & .427 & 92.28 & .0001 & -.135 & -3.96 & .0001 \\
\hline 5 & Self-direction & .662 & .438 & 76.97 & .0001 & .145 & 3.07 & .002 \\
\hline
\end{tabular}

*Dependent Variable: WTC- total; constant: 132

As illustrated in Table 3, those participants who valued openness to change (54\%), selfenhancement (61\%), universalism (64)\%, tradition (65\%), and self-direction (66\%) above others were better predicators of WTC total $(\mathrm{p}<.01)$.

\section{T-tests for males and females}

To explore whether the differences in gender had a significant impact on the participants' value orientations and its subcategories and the total WTC and its subcategories, a series of independent samples $t$ - tests were run the results of which appears in Table 4 below:

Table 4. Independent T-test on the effect of gender on WTC and PVQ total and their subcategories

\begin{tabular}{l|c|c|c|c|c|c|c}
\hline & \multicolumn{2}{|c|}{ Female $(\mathrm{n}=272)$} & \multicolumn{2}{c|}{ Male $(\mathrm{n}=228)$} & \multirow{2}{*}{ Sig } & \multirow{2}{*}{$D$} \\
\cline { 1 - 4 } WTC Components & $\mathrm{M}$ & $\mathrm{SD}$ & $\mathrm{M}$ & $\mathrm{SD}$ & & & \\
\hline Speaking & & & & & & & \\
\hline Reading & 3.09 & .97 & 2.83 & .92 & 3.08 &. $\mathbf{0 0 2}$ & .26 \\
\hline Writing & 3.31 & 1.03 & 3.12 & 1.02 & 2.02 &. $\mathbf{0 4}$ & .18 \\
\hline Comprehension & 2.97 & .96 & 2.86 & .94 & 1.32 & .18 & .11 \\
\hline WTC total & 3.38 & 1.00 & 3.28 & 1.03 & 1.19 & .23 & .10 \\
\hline Value orientations & 3.56 & .90 & 3.47 & .98 & 1.10 & .27 & .093 \\
\hline Power & & & & & & & \\
\hline Achievement & 4.09 & .61 & 4.10 & .69 & -.22 & .82 & -.01 \\
\hline Hedonism & 3.09 & .91 & 3.13 & .92 & -.55 & .57 & -.04 \\
\hline Stimulation & 3.71 & .74 & 3.74 & .77 & -.55 & .58 & -.03 \\
\hline Self-direction & 3.50 & .88 & 3.60 & 2.03 & -.75 & .45 & -.10 \\
\hline Universalism & 3.48 & .90 & 3.48 & .95 & .09 & .92 & .00 \\
\hline Benevolence & 3.93 & .67 & 3.85 & .78 & 1.21 & .22 & .08 \\
\hline Tradition & 4.02 & .94 & 4.02 & 74 & -.05 & .95 & -.00 \\
\hline Conformity & 3.72 & .90 & 3.75 & .85 & -.39 & .69 & -.03 \\
\hline Security & 3.48 & 1.86 & 3.46 & .83 & .08 & .93 & .01 \\
\hline Openness to change & 3.56 & .62 & 3.61 & .87 & -.63 & .52 & -.04 \\
\hline Self-enhancement & 3.59 & .61 & 3.62 & .66 & -.51 & .60 & -.02 \\
\hline Conservation & 3.70 & .77 & 3.68 & .56 & .29 & .76 & .01 \\
\hline Self-transcendence & 3.97 & .65 & 3.93 & .61 & .67 & .50 & .03 \\
\hline
\end{tabular}

Based on Table 4, the obtained means for the effect of gender on the participants' values and WTC total, it can be seen that none of these two variables were affected by gender. While some subcategories of WTC such as that of willingness to speak (.002) and willingness to read (.004) 
were found to have been significantly affected by gender those related to PVQ (self-direction, stimulation, benevolence, tradition, achievement, security, universalism, conformity, power, hedonism, openness to change, self-enhancement, and self-transcendence) were not in any way affected by the participants' gender.

\section{Conclusion}

The results of this study revealed that there is a positive relationship between overall WTC and value orientation as well as WTC subcomponents and value orientation. Furthermore, the results obtained through stepwise regression analysis indicated that in terms of values, openness to change, self-enhancement, universalism, tradition, and self-direction are better indicators of overall WTC. The findings also indicated that although gender affected participants' willingness to read and speak in the classroom, it did not have any significant effect on their value orientations. The findings of the present study can advance our understanding of the nature of the relationship between basic human values and willingness to communicate among Iranian university students.

\section{Implications}

Based on the findings of this study, these implications are drawn to the EFL learners, teachers, and material developers.

Through identifying their value orientations, learners in general and EFL learners in particular, can obtain a better understanding of their personal experiences within the language classroom. They can also gain a better understanding of why their peers do what they do in the classroom. All these can help in ensuring equal distribution of power within the classroom or at least in increasing participation among the students.

EFL teachers can recognize that students' performance within the classroom is affected by many factors such as their value orientations. When a teacher realizes this, s/he will not attribute a student's silence within the classroom to his/her lack of proficiency or preparedness. Accordingly, the teacher can modify her/his practice within the classroom and help students create a balance between their value orientations by discussing with them about the issue.

People in different contexts might have different value orientations; therefore, material developers should recognize the necessity to develop some context-specific materials based on learners' needs and orientations. They can help in creating a balance between learners' different value orientations through presenting the language in an appropriate way and through paying attention to different value orientations and the way they can facilitate or prevent language learning. In this way, different learners will be involved in and take responsibility for their own learning.

\section{References}

Allport, G. W., Vernon, P. E., \& Lindzey, G. (1960b). Test booklet: Study of values (3rd ed.). Boston: Houghton Mifflin Company. 
Basbakanlik. (2010). Turkiye 'de aile degerleri arasturmasi. TC Basbakanlik Aile ve Sosyal Arasturmalar Mudurlugu (Ed. Mustafa Turgut).

Beill, B. (2003). Iyi çocuk-zor çocuk: doğru davranışlar çocuklara nasıl kazandırılır?. Ankara: Arkadaş Yayınları

Burgoon, J. K. (1976). The unwillingness to communicate scale: Development and validation. Communication Monographs, 43, 60-69.

Canale, M., Swain, M. (1980). Theoretical bases of communicative approaches to second language teaching and testing. Applied Linguistics, 1, 1-47.

Döring, A. K. (2010). Assessing children's values: An exploratory study. Journal of Psychoeducational Assessment, 28(6), 564-577.

Dornyei, Z. (2003). Attitudes, orientations, and motivations in language learning: Advances in theory, research, and applications. Language Learning, 53(Suppl. 1), 3-32.

Dummett, M. (1981). Frege: Philosophy of Language, 2nd edition. Harvard University Press: Cambridge, MA

England, G. (1967). Organizational goals and expected behavior of American managers. Academy of Management Journal, 10, 107-117.

England, G. W. (1975). The manager and his values. Cambridge, MA: Ballinger.

England, G., \& Lee, R. (1971). Organizational goals and expected behaviour among American, Japanese, and Korean managers-A comparative study. Academy of Management Journal, 14, 425-438.

Fichter, J. (1990). What is sociology?. Konya: Selçuk Üniversitesi Yayınları.

Guth, W. D., \& Tagiuri, R. (1965). Personal values and corporate strategy. Harvard Business Review, 43, 123-132.

Hofstede, G. H. (1980). Culture's Consequences: International Differences in Work-Related Values. Thousand Oaks, CA: Sage.

Kang, S. (2005). Dynamic emergence of situational willingness to communicate in a second language. System, 33, 277-292.

MacIntyre, P. D., Clément, R., Dörnyei, Z., \& Noels, K. A. (1998). Conceptualizing willingness to communicate in a L2: A situational model of L2 confidence and affiliation. Modern Language Journal, 82, 545-562.

McCroskey, J. C., Richmond, V. P. (1987). Willingness to communicate. In J. C. McCroskey \& J. A. Daly (Eds.), Personality and interpersonal communication (pp.129-156). Newbury Park, CA: Sage

Oyadomari, J., Teixeira, M., Nisiyama, E., Cardoso, R. (2008). Personal values and MCS dysfunctional use: An exploratory study. https:/www.yumpu.com/en/document/view/5522519/personal-values-and-mcsdysfunctional-use-anpcont

Ozsoy, S. (2007). Degerlere dayali bir ortam yaratmak esittir daha iyi dunya yaratmak. Ilk Ogretmen Dergisi, 14, 30-34.

Rohan, M. J. (2000). A rose by any name? The values construct. Personality and Social Psychology Review, 4, $255-$ 277.

Rokeach, M. (1973). The Nature of Human Values. New York: Free Press.

Schwartz, S. H. (1992). Universals in the content and structure of values: Theory and empirical tests in 20 countries. In M. Zanna (Ed.), Advances in experimental social psychology (Vol. 25) (pp. 1-65). New York: Academic Press.

Schwartz, S. H. (1994). Are there universal aspects in the content and structure of values? Journal of Social Issues, $50,19-45$.

Schwartz, S. H., Melech, G., Lehmann, A., Burgess, S., \& Harris, M. (2001). Extending the cross-cultural validity of the theory of basic human values with a different method of measurement. Journal of Cross-Cultural Psychology, 32, 519-542. 
Schwartz, S. H., Rubel, T. (2005). Sex differences in value priorities: Cross-cultural and multi-method studies. Journal of Personality and Social Psychology, 89.

Skehan, P. (1989). Individual Differences in Second Language Learning. London: Edward Arnold.

Spranger, E. (1928). Types of men: The psychology and ethics of personality (P. J. W. Pigors. Trans.). Halle: Max Niemeyer.

Tagiuri, R. (1965). Value Orientations and the Relationship of Managers and Scientists. Administrative Science Quarterly, 10(1).

Williams, R. M., Jr. (1968). Values. In E. Sills (Ed.), International encyclopedia of the social sciences. New York: Macmillan.

Zarrinabadi, N., Abdi, R. (2011). Willingness to Communicate and Language Learning Orientations in Iranian EFL Context. International Education Studies 4(4), 206-214 